\title{
Erasmus+ and Vocational Secondary Education: Analyzing Participating Students' Views. A Case Study of Students' Mobility in the Prefecture of Preveza, Greece
}

\author{
Aggelos Kavasakalis (Corresponding author) \\ University of Patras and Hellenic Open University \\ Dimokritou 18, 16343, Ilioupoli, Athens, Greece
}

Tel: 30-697-402-5628

E-mail: a.kavasakalis@gmail.com; agkav@upatras.gr

\begin{abstract}
Maria Tzima
MSc in Education Sciences - Hellenic Open University, Greek Literature Teacher Vocational Secondary Education

Kanari 1, 48100, Preveza, Greece

E-mail: mariatzima10@gmail.com
\end{abstract}

Received: March 24, 2020

Accepted: May 15, $2020 \quad$ Published: August 20, 2020

doi:10.5296/jet.v7i2.16736

URL: http://dx.doi.org/10.5296/jet.v7i2.16736

\begin{abstract}
After the advent of the knowledge society there has been a lot of debate, among countries and supranational organizations, on the promotion of lifelong learning policies and cooperation policies on education and training issues. In this context, training policies and mobility programmes at all levels of education and/or training are high on the international political agenda.

At the same time, it is well known that vocational education and training is inextricably linked to the labour market and undoubtedly to employability (Stamelos, Vasilopoulos, Kavasakalis, 2015). Within this broader framework, many policies and programmes have been developed and implemented at European level to defend this objective, with the most contemporary of them, Erasmus + . This article presents a case study of a students' mobility programme.

In detail, the purpose of this article is to investigate and analyse the participating students' views in individual mobility actions under the Erasmus + programme in secondary vocational
\end{abstract}


education in the prefecture of Preveza, regarding the effectiveness in achieving the objectives set by the programme itself.

The text is divided into two subsections. The first section analyses the most important parameters of the issue at European and national level, as well as the basic structures and actions implemented within the framework of the European Erasmus + Programme, while the second presents the research methodology and the primary results extracted from the descriptive and statistical analysis of the research tool, i.e. the questionnaire answered by Erasmus + participants after the mobility.

Keywords: Vocational Education, Students' Mobility, Erasmus+, European Education and Training Policies

\section{European Education Policies in the New Century: Setting the Wider Scene}

\subsection{Knowledge Society and Lifelong Learning Policies}

Over the years, lifelong learning and training policies have developed in the European area in a globalised environment. The latest developments in technology, information, and the productive and labour structures have led to a form of revolution that is compared, by many, with the industrial one and they are reflected in the educational policies implemented, while through these policies the so called "Knowledge Society" is formed (Kavasakalis, 2018: 357). The knowledge society, focusing on its knowledge and production, defines the condition of social and economic survival of individuals through processes of post-education, training and ultimately lifelong learning. However, given that knowledge is a necessity, the modification of terminology from the initial "lifelong education" to today's "lifelong learning" and the introduction of individual responsibility and choice could be interpreted. Knowledge is now a resource, which ensures quality and adequacy in a person's life. The consequence of all these is, according to Tsaousis (2007), that we move from the perception of knowledge as a perpetual estate to knowledge as a consumable commodity whose duration is constantly reduced. The emphasis on teaching, knowledge and the profession give way to learning, knowledge demand and employment or (now) employability (Kavasakalis, 2018, p. 370).

The main axes (principles) of the implementation of a structured knowledge society are the following (Kelpanidis \& Vrynioti, 2004):

- The promotion and defense of the participatory process within a society of this kind.

- The optimal level of coordination and complementarity of the relevant educational policies adopted by this society to achieve its objectives and goals.

- The empowerment of all kinds and types of knowledge used.

An important point is the relationship that has been noticed between the knowledge society, the lifelong learning and employability. To be more specific, these three concepts have a relationship of relevance and complementarity. They may also be characterized as 'cause-effect' relationships, since the existence of the knowledge society, through its development tools, increases the individuals' ability to comprehend the meaning of lifelong learning which, in turn, increases the degree of competitiveness of the individuals in the labour market, thus helping 


\section{N Macrothink

them to obtain a satisfactory employment for them in the economic - social environment where they live and operate. In this way, employability is promoted to the final stage (OECD, 1997).

At the same time, Brown, Hesheth \& Williams (2003) are considering an opposite-oriented course of employability in relation to lifelong learning and the knowledge society. More specifically, according to Brown et al. (2003), the degree of employability and competitiveness, regarding a person's jobs, is gaining high weight if the person, apart from formal education, has also attended various lifelong learning programmes during his life.

\subsection{Relation between Lifelong Learning and Lifelong Education-Training and Employment Policies}

There is direct link and interdependence between the concepts of lifelong learning and lifelong vocational training regarding people's employment (Brennan, Mills, Shah \& Woodley, 2000). The concept of employment of individuals is often referred to as 'employability' in the existing bibliography. Employability is defined as the ability to enter and then remain in a specific job, under any circumstances and in whatever field this job belongs to (Brennan et al., 2000). According to McQuaid \& Lindsay (2005) employability means the development of skills, knowledge, technology and adaptability that help a person enter the labour market and remain in it throughout a working life. Hillage \& Pollard (1998) define employability as the individuals' ability to move, sustainably, within the changing labour market by using the knowledge, skills and attitudes they have developed. The way all these are presented to the employers also plays a very important role. Jenkins (2004) also attempts to link employability to the changing labor market by defining the specific duration of employment in a particular job as its characteristic.

This is precisely the relationship highlighted by Moreau \& Leathwood (2007), in their research on the employment of university graduates and the causes of the level of the overall employability. In particular, according to the researchers in the competitive global labour market, what is needed for a job to be obtained, is not only the adequate level of the individuals' knowledge but also the overall structured personality of each and the competences that this person has developed and improved during his lifetime.

In addition, employability is inseparably linked to the following factors:

- The individual himself and his professional skills that he has managed to develop during his life, and which must be highly competitive and attractive to the demanding labour market.

- The identity of the individual, in respect to the characteristic of sociability (social identity) (Note 1). (Jenkins et al., 2003)

Finally, it should be noted that lifelong learning policies correlate with the efforts to deal with the consequences of the advent of the knowledge society and, in particular, globalization (Note 2 ), as the policies are designed to face the continuous changes in the working environment and thus in the effort to enhance employability. 
1.3 The Framework of Globalization in the Field of Education and Vocational Training

According to Aliber \& Click (1993), the phenomenon of globalization and its integration into all the activities and functions of the economic and social life of a place, promotes the different way of thinking and the different cultures, while simultaneously enhances the overall development of the society in which they exist. According to Hirst, Thompson \& Bromley (2009), globalization has an impact mainly on developed societies and brings about higher competition in the labour market.

Since, education and vocational training is an important component of the organization of a State, they are bound to be influenced by current developments (Stromquist \& Monkman, 2014). With regard to the relationship between globalization and education, Carnoy \& Rhoten (2002) concluded that the phenomenon of globalization inevitably caused educational changes in various States worldwide because the process of education and lifelong learning are linked to modern economic reality (Note 3). European Union also acts under these international conditions, and it promotes political, social and economic cooperation among its Member States. Adapting its Member States to common areas of education policies, in order for them to achieve common objectives, is not an easy process. As shown in Dale's study (2010) in the delimitation of the effects of globalization on the system of national education policies, three basic policy axes are detected. These axes are applied by the EU to lead its Member States towards common education policies:

- By creating consolidated official documents, which bind all Member States to their terms.

- By financing educational programs.

- By participating in European networks consisting of international organizations, NGOs, private institutions, research institutes, all of which are established bodies of the education policy pursued, and also by financing mobility actions and the exchange of practices (Socrates, Comenius, Erasmus, Tempus, Erasmus+, etc.).

\subsection{European Programmes on Education and Training: An Initial Reference}

A landmark for the development of European education policies and, by extension, for the design of European educational programmes, was the 1990s when the European Union was founded and the concepts of lifelong learning, vocational education and training were established (as possible EU policy areas) and mobility policies were strengthened.

According to Boutsiouki (2017), the two European programmes designed and aimed at strengthening vocational training and lifelong learning were the Socrates programme and the Leonardo Da Vinci programme.

Socrates included actions and activities in all areas of education while its main objectives were to improve the field of education at European level, to establish equal education opportunities, to promote innovation, to improve the quality of education and to increase the mobility of the European population and finally to improve the participants' language skills (Gonzalez \& Wagenaar, 2003).

Leonardo Da Vinci was also developed in the 1990s. Its objectives were to improve the 


\section{Mll Macrothink}

Journal of Education and Training

ISSN 2330-9709

2020, Vol.7, No.2

professional capacities - skills of human resources in order to develop competitiveness, to strengthen vocational training by contributing innovative elements and to develop, to the fullest extent, vocational education and training through lifelong learning and continuing vocational training (Boutsiouki, 2017).

After 2000, due to the particular requirements of the time, the training programmes carried out until then have changed radically, adopting in their processes the overall philosophy of lifelong learning (Stamember \& Vasilopoulos, 2013). Thus, the EU created the Lifelong Learning Program (LLP) 2007-2013. The overall objective of the programme was to contribute, through lifelong learning, to the development of the Community as an advanced knowledge-based society, with sustainable economic growth, better and more jobs and greater social cohesion, while ensuring satisfactory environmental protection for future generations. In particular, it aimed at synergies, exchanges and facilitation of mobility among education and training systems in the EU.

In 2014, the "Erasmus for All" programme, also known as "Erasmus+" was developed (Note 4), and it is fully adapted to the advanced lifelong learning society (Member et al., 2015).

\section{European Educational Programme: Erasmus+}

The European Erasmus + educational programme was essentially the sophisticated form of previous EU actions which had a direct link to education and education policy, fully adapted to the 'present' (European Commission, 2020a).

Erasmus + , among other things, enhances people's skills at European level as well as their employability and contributes to the modernization of education systems in all areas consistent with Lifelong Learning. The following table lists the actions of the Erasmus + programme:

Table 1. Erasmus+ Actions

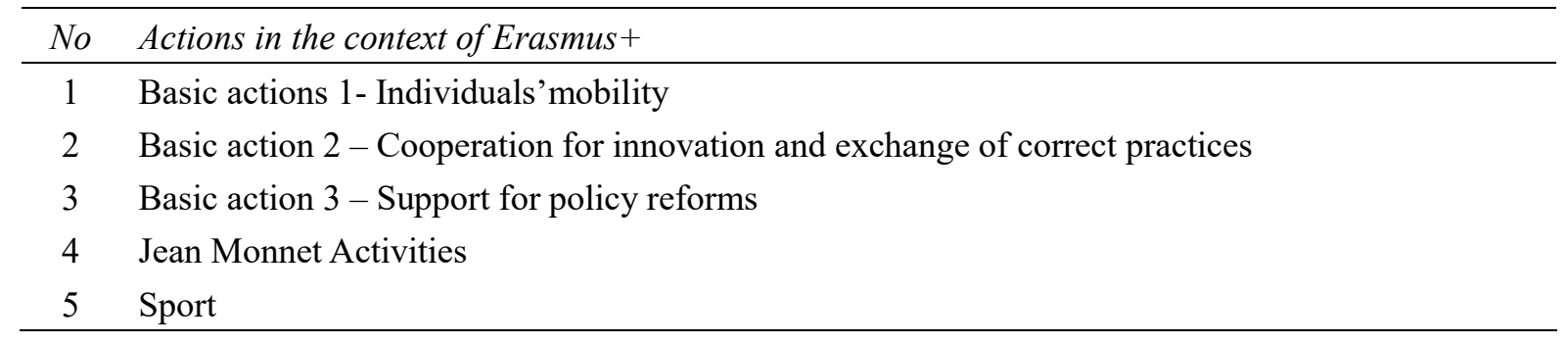

Source: European Commission 2020a, European Commission 2020b

\subsection{Key Goals and Objectives}

All the actions carried out for the European Erasmus + programme are directly related to the general and specific objectives of the programme and contribute, at European and international level, to the following points:

- Improvement of the sports sector.

- Mobility.

- Cooperation in order to achieve innovation and the exchange of appropriate practices. 


\section{Macrothink Mnstitute"}

- Support of reforms relating to the policy carried out.

The main objective of the European Erasmus+ programme is to strengthen vocational education and training of both young people and others involved, through the actions it provides, and to strengthen the sports sector, always at European level (Stamelos et al., 2015).

According to No. 1288/2013 EU Regulation (Official Journal of the European Union, 2013), the objectives of the Erasmus+ program are distinguished in general and specific ones:

Table 2. Erasmus + General and Specific Objectives

Erasmus + General objectives

Erasmus + Specific objectives in the field of education and job training

The enhancement of the level of basic skills - competences in

To achieve the objectives of the

"Europe 2020" strategy

To achieve the objectives of the strategic framework for European cooperation on the field of education and job training 'ET 2020'

To enhance the sustainable development of participating countries in the field of higher education

To strengthen European cooperation as far as youth is concerned

To contribute to the achievement of the objectives of the EU Work Programme for Sport, in particular for mass sport

To promote European values as described in Article 2 of the Treaty of European Union relation to labour market needs and social cohesion through learning mobility and cooperation between education and training and the world of work.

The enhancement of the cooperation between educational organisations and other bodies with a view to promoting innovation, improving quality and promoting their internationalisation

The reform of national education policies through the creation of a European area of lifelong learning, the enhancement of transparency, the use of common means and the dissemination of good practices

The enhancement of the international dimension of education and training, in particular through partnerships between educational institutions in the field of VET and higher education

The development of the intercultural consciousness of participants and the linguistic diversity of the EU through the improvement of language teaching and learning

Source: European Commission 2020b

By setting the general and specific objectives, the Erasmus + programme promotes the convergence of education policies through the internationalization of educational organizations, especially those of higher education. Erasmus + upgrades the role of Lifelong Learning and facilitates the mobility of learners and staff by removing various obstacles. The programme also promotes the convergence between the world of labour market and education and improves competitiveness.

\subsection{Mobility and Erasmus +}

In order for the objectives of the program to be achieved, particularly in the field of education 
and training, specific activities are presented in all three Main Actions. Specifically:

- Mobility projects for students and staff in Higher Education and trainees in vocational education and training (VET).

- Mobility Projects for school and adult education staff

- Joint Postgraduate Programmes of Erasmus Mundus

- Erasmus + postgraduate loans.

- Strategic Partnerships

- Knowledge Alliances-European Universities

- Sector Skill Alliances

- Skill/capacity development in the field of higher education.

(Erasmus+ Program Guide, 2020)

The main form of activity in the European Erasmus + program is the mobility of individuals, i.e. geographical movement for a specific period of time, from the country of their permanent residence to another country for learning purposes and/or for gaining professional experience. The mobility consists in:

- Mobility of learners, educators and staff: it enables, inter alia, students, learners, teachers and staff to gain educational and/or professional experience in another country.

- Joint Postgraduate Programmes of Erasmus Mundus Studies: collaborating higher educational institutions jointly organize international curricula attended by postgraduate students with high educational qualifications

- Erasmus Postgraduate Studies Loans: higher education students, from countries participating in the programme, are given the opportunity to obtain a loan for postgraduate studies

(Erasmus+ Program Guide, 2020).

\subsection{The Concept of Effectiveness of Programmes and Educational Policies}

Each programme or education policy is usually judged and evaluated through its effectiveness, in accordance with the achievement or not of the predefined objectives it has set. This is precisely what is happens in educational European programmes and in the respective educational policies implemented for this purpose (Boutsiouki, 2017).

The effectiveness of the European education programmes (Note 5) concerns five main axes: employment and labour market, ensurance of the quality of vocational education and training through lifelong learning, social cohesion, mitigation of inequalities and human resource competition. (Gouvias \& Therianos, 2014). In this article we focus on investigating the effectiveness of one action axis of the Erasmus+ programme. 


\section{$\Lambda$ Macrothink}

\section{Research Methodology}

\subsection{Research Questions}

The aim of the research presented in this article was to investigate the effectiveness of a mobility program within the framework of Erasmus + , by analyzing the responses given by the students who participated in the particular action of the programme.

This is why the views of the participating students on the following issues are being examined:

- The quality of the studies/education received by the participants.

- The importance of the certification and the official recognition they received.

- The language skills developed through the programme.

- Their personal development.

- The future prospects of the participants.

- The practices and the organizational arrangements of the program.

- The accommodation services and the infrastructure.

- The funding.

The research questions raised in the research presented in this article are the following:

- Are actions towards acquiring and/or improving knowledge and skills related to vocational education and training effective?

- Are actions towards improving skills related to foreign languages, effective?

- Are actions in terms of personal improvement and development of participating students effective?

- Are actions in terms of improvement in future employment and careers of participants effective?

\subsection{Research Tools - Questionnaire}

Our analysis used data from the official program questionnaire (Note 6) completed by students who took part in the mobility program. After the end of each mobility, the school gathers all its elements on an online platform (Note 7). Participants then receive an individual invitation via the platform in their personal e-mail and via link they are connected to a website to complete the report within 30 days. After the reports are submitted by all participants in the mobility plan, the mission organization (school unit) shall submit them together with other supporting documents to the Erasmus+ National Agency (Note 8).

This research tool consists of 11 main modules containing closed and open-type questions. In more detail, the modules of the questionnaire are as follows: 


\section{Macrothink}

Table 3. Questionnaire Modules

\begin{tabular}{ll}
\hline Module 1 & Purpose of the participant report \\
Module 2 & Identification of the Participant and General Information \\
Module 3 & Quality of Studies/ Training \\
Module 4 & Foreign Language Skills and Linguistic Support \\
Module 5 & Certification and Formal Recognition \\
Module 6 & Personal Development \\
Module 7 & Future Prospects of Education, Training and Work \\
Module 8 & Practical and Organisational Arrangements \\
Module 9 & Costs \\
Module 10 & Conclusions, Personal Comments and Recommendations \\
Module 11 & Publication and Usage Rights of the Information and of the Email Address \\
\hline
\end{tabular}

The total number of questions in the questionnaire is 38 and there are some categories of the factors (above) are examined. In this paper, a number of categories of the factors were selected for the analysis and processing of the research data. The factors and our selection are shown in the table below:

Table 4. Factors of the questionnaire and selection of factors for the research

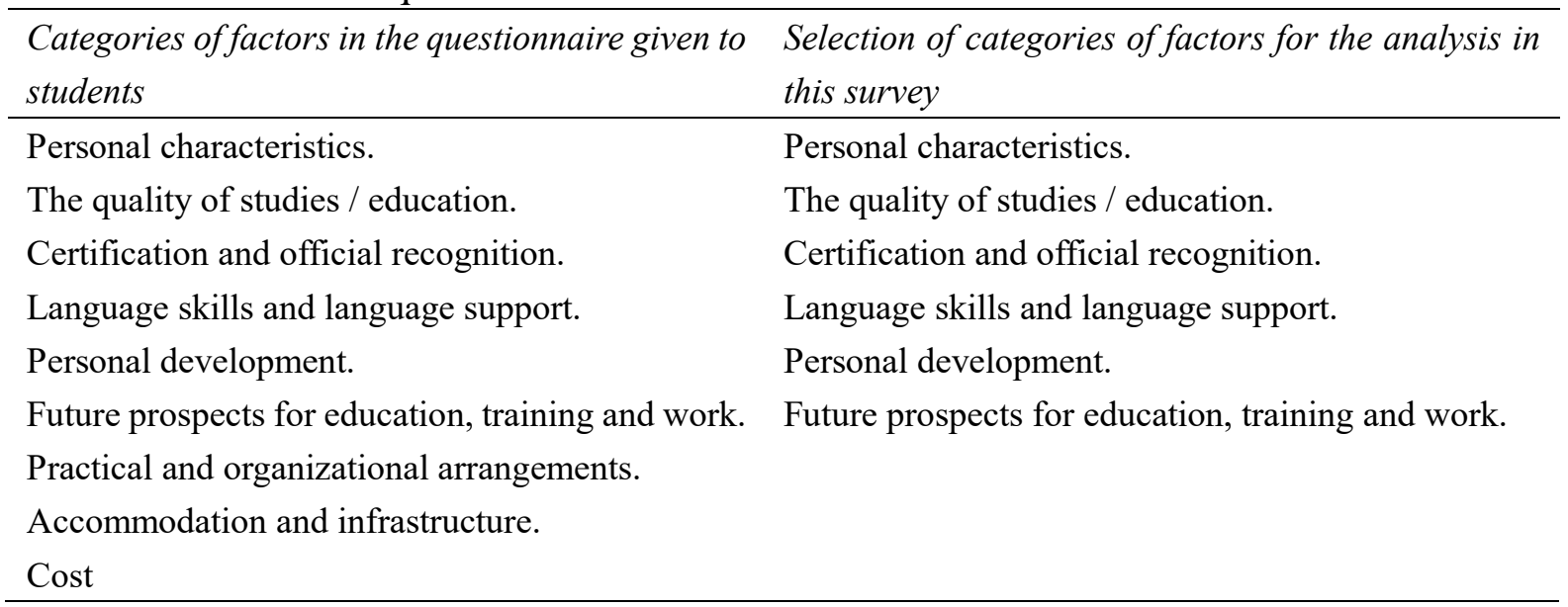

\subsection{Research Identity}

The research focuses on Erasmus + mobility programmes that have been implemented by school units belonging to upper secondary vocational education, exclusively in the Prefecture of Preveza, and so the population is identified with the sample used in the investigation. This is due to the fact that in the prefecture of Preveza the school units that participated in mobilities were the $1^{\text {st }}$ Vocational High School of Preveza, the $1^{\text {st }}$ Laboratory Center of Preveza and the $1^{\text {st }}$ Vocational High School of Filippiada, Preveza.

The population - sample used for the needs of the survey was 255 participating students. The programmes examined were implemented from 2015 to 2018 (Note 9).

The statistical analysis of the data consists of two analyses: the regression and correlation analysis.

The regression analysis developed in the next five stages: 
- $\mathrm{R}^{2}$ was evaluated.

- The regression factor (b) was identified and evaluated on the basis of the corresponding criterion.

- Statistical significance (F) was interpreted.

- The p-value (constant) and p-value of the independent variable were evaluated.

- Regression equations have been formulated.

The correlation analysis applied after factor analysis and the extraction of factors (independent variables). It was carried out to identify a possible statistical correlation between the variables mentioned above.

The reliability and validity test was conducted through the validity of the variable, the content validity and the reliability test.

The test of the validity of the variables was carried out through the factor analysis of the scales used in the questions of the research tool given to the participating students.

The criterion for the degree of the reliability of the research scales is the reliability coefficient Cronbach's Alpha (a), which may receive values ranging from zero (0) to one (1).

\section{Presentation of the Findings and Analysis}

\subsection{Descriptive Data Analysis: Findings}

The total number of the students involved in this survey and used as a sample is $255(\mathrm{~N}=255)$.

From the sample, $50 \%$ of the students were in the second year of their level of study $\left(2^{\text {nd }}\right.$ grade EPAL), $49 \%$ in the third year $\left(3^{\text {rd }}\right.$ grade EPAL) and only $1 \%$ were already graduates.

\subsubsection{Student Motivations for participation in the program}

The motivations that led students to choose studies/training abroad, according to their answers to the corresponding question, are summarized in the following table:

Table 5. Students' main motivations

\begin{tabular}{lc}
\hline $\begin{array}{l}\text { Students' main motivations for carrying out a learning mobility period abroad } \\
\text { on Erasmus + programme }\end{array}$ & $\begin{array}{c}\text { Number of answers } \\
\text { (N=255) }\end{array}$ \\
\hline Enhance my technical/professional skills/competences & 166 \\
Opportunity to meet new people & 112 \\
Enhance my future employability abroad & 110 \\
Opportunity to live abroad & 98 \\
Opportunity to experience different learning practices & 91 \\
Opportunity to learn/improve a foreign language & 90 \\
Enhancement my future employability in my home country & 74 \\
Good alignment of the courses/training abroad with the curriculum at the & 71 \\
sending institution & 69 \\
Quality of the receiving institution & 42 \\
Opportunity to develop personal skills, such as adaptability & 34 \\
The length of the study/training period was appropriate & 21 \\
Possibility to choose to do part of my studying/training in a foreign language & \\
\hline
\end{tabular}


It was also found that the organization that hosted the examined sample abroad was a business, and $98 \%$ of the students would recommend it to other people. Only $2 \%$ gave a negative answer.

It was observed that the prevailing language used during the activity of mobility was English with a $98 \%$ response rate, while only $2 \%$ replied that the main language used was Greek.

Regarding the students' opinion concerning the improvement of their language skills in the main language used during their stay abroad, $86 \%$ of them believe that their language skills have not improved because they had already been speaking fluently. $14 \%$ of the students responded that their language skills have been improved and none of them $(0 \%)$ chose the answer of complete refusal on the specific skill.

For the additional language skills developed by the students during of mobility activity, besides the main language, $81 \%$ of the students considered that they have not improved their language skills in another language, while $19 \%$ of the students considered that there has been an improvement in their language skills apart from the main language and in particular in the language of the host country.

What is very important is the fact that the learning outcomes of the Erasmus + mobility period have been recognized for all the mobility participants.

As regards the type of recognition received by the students, $79 \%$ received certification through Europass Mobility Document and a Certificate of Attendance from the host institution, 16\% received only Europass Mobility Document, 3\% of the students received Europass Mobility Document and a Work Certificate, while $2 \%$ of the students received only a Work Certificate.

4.1.2 Students' Satisfaction from the Overall Experience of the Erasmus+ Mobility Programme The participating students' satisfaction from the overall experience of mobility through the Erasmus + programme ranges at very high levels, with $95.29 \%$ of the students in the sample stating they are very satisfied with this mobility activity. In particular, the corresponding percentages are as follows:

$-95.29 \%$ of the students seem to be very satisfied with the Erasmus + programme in which they participated.

$-3.92 \%$ of the students say they are rather satisfied with the overall Erasmus + programme.

$-0.79 \%$ of the students are neither satisfied nor dissatisfied with the mobility programme.

- $0 \%$ of the students stated rather dissatisfied/very dissatisfied.

\subsection{Factor Analysis: Findings}

The factorial analysis identified the independent variables as well as the reliability of the survey's scales-questions through the Cronbach's reliability coefficient a. The total specific variance, eigenvalue and reliability factor were calculated.

Scales with an eigenvalue larger than 1 were selected, according to the Kaiser criterion. 


\section{Macrothink}

Cronbach's values a $>0.7$ were accepted to characterize the scale reliable. For the validity of the scales, the factor loading values of the variables were also calculated in order to identify their gravity in the interpretation of the factors. Factor loading values $>0.5$ were accepted.

The variables that did not meet this criterion were rejected along with the factors containing them.

The factor analysis carried out as described above showed 17 important factors. These factors, the scale to which they belong, their average value, and the standard deviation are aggregated in the table below.

Our analysis has shown that the factors are interpreted with great or satisfactory gravity by their variables. Variables that did not meet the criterion ( $0.5>$ factor loading) were not accepted for the follow-up of the analysis and nor were the factors containing them. Therefore, the questions - scales of the student questionnaire, to which the above acceptable factors belong, also define the objectives of the programme.

Table 6. Aggregate table of averages - standard deviations of factorial analysis factors

\begin{tabular}{lllc}
\hline \multirow{2}{*}{ Scales } & Factors & Averages & $\begin{array}{c}\text { Standard } \\
\text { deviations }\end{array}$ \\
\hline \multirow{2}{*}{$\begin{array}{l}\text { Support quality to the sending and receiving } \\
\text { organisation }\end{array}$} & 1. Help & 1443 & 0,773 \\
& 2. Facilities \& equipment & 1340 & 0,594 \\
& 3. Trainee's needs and organization & 1383 & 0,582 \\
Development of skills & 4. Astuteness & 1841 & 0,835 \\
& 5. Contemporary skills & 1415 & 0,760 \\
& 6. Perception abilities & 1817 & 0,958 \\
Trainee's improvement & 7. Way of thinking & 1623 & 0,734 \\
& 8. Organization/Cooperation in the & 1682 & 0,746 \\
Positive aspects-outcomes of participating in the & 10. Improvement through teamwork & 1497 & 0,623 \\
mobility activity & 11. New challenges/situations & 1521 & 0,636 \\
& 12. Critical mind & 1540 & 0,645 \\
Future prospects from the mobility experience & 13. Interest in exogenous factors & 1602 & 0,656 \\
14. Job opportunities & 15. Perception on work issues & 1615 & 0,682 \\
\hline
\end{tabular}

\subsubsection{Correlation Analysis Based on Data from Students' Responses to the Questionnaires}

Based on the factorial analysis that preceded, the independent variables of the research process are defined. These variables identify with the factors already accepted in Table 6.

The above independent variables were examined for their correlation with the dependent variable "Satisfaction from the Erasmus+ mobility overall experience". 


\section{Macrothink}

After the analysis of the correlations, it was found that the independent variables "Astuteness (skills)", "New challenges /situations", "Perception on work issues" and "Working in an international context" have a greater correlation with the dependent variable "Satisfaction from the Erasmus+ Mobility Experience". All the other independent variables showed smaller correlations with the dependent variable.

Table 7. Correlation coefficient rates of independent - dependent variables

\begin{tabular}{ll}
\hline Correlations between the independent variables and the dependent variable & Correlation coefficient $(r)$ \\
"Satisfaction from the Erasmus + mobility overall experience ", & 0.16 \\
\hline Help & 0.57 \\
Facilities \& equipment & 0.17 \\
Trainee's needs and organization & $\mathbf{0 . 6 8}$ \\
Astuteness & 0.14 \\
Contemporary skills & 0.49 \\
Perception abilities & 0.56 \\
Way of thinking & 0.31 \\
Organization/Cooperation in the team & 0.09 \\
Personal improvement & 0.24 \\
Improvement through teamwork & $\mathbf{0 . 9 8}$ \\
New challenges/situations & 0.13 \\
Critical mind & 0.34 \\
Interest in exogenous factors & 0.35 \\
Job opportunities & $\mathbf{0 8}$ \\
Perception on work issues & $\mathbf{0 . 8 4}$ \\
Working in an international context & 0.05 \\
\hline
\end{tabular}

\subsection{Regression Analysis: Findings}

A regression analysis was then carried out to identify the relationship between the correlated independent variables and the dependent variable "Satisfaction from the Erasmus + overall experience" in the students' sample. For this reason the dependent variable was encoded as follows:

$\mathrm{H}_{0}$ : If the student stated that he was not satisfied with the overall experience of Erasmus $+\left(\mathrm{H}_{0}\right)$ $\mathrm{H}_{1}$ : In all other responses given by students because they are considered as a measure of satisfaction $\left(\mathrm{H}_{1}\right)$

The first regression analysis was carried out between the dependent variable "Satisfaction from the Erasmus+ overall experience" and the $1^{\text {st }}$ independent variable "Help". The results are presented in the following table. 


\section{Macrothink}

Journal of Education and Training

ISSN 2330-9709

2020, Vol.7, No.2

Table 8. Regression analysis' results between Dependent Variable- 1st Independent Variable "Help"

\begin{tabular}{ll}
\hline Multiple R & 0,8819 \\
$\mathrm{R}^{2}$ & 0,7778 \\
Adjusted $\mathrm{R}^{2}$ & 0,7739 \\
Std. Error & 0,4722 \\
Statistical significance F & 83995 \\
$\mathrm{~B}_{0}$ & 0 \\
Bhelp $_{\mathrm{P}_{\text {value (constant) }}}$ & 0,5405 \\
$\mathrm{P}_{\text {value (help) }}$ & - \\
\hline
\end{tabular}

Regression coefficient $b$ is as follows: $b=B_{0}+B_{\text {help }}$

Therefore, the regression coefficient $b=0,5405$.

Between the two variables there is a positive correlation, which means that as the 'Help' variable increases, the overall satisfaction of this mobility experience also increases (as well).

The regression equation takes the following form: $\mathrm{Y}=\mathrm{B} 0+(\mathrm{Bi} \cdot \mathrm{xi})$, (where $\mathrm{xi}$ is the value of the independent variable) (Note 10).

Consequently, $\mathrm{b}=0.5405(>0)$ so $\mathrm{H}_{0}$ is rejected and we accept $\mathrm{H}_{1}$.

Table 9 below shows the rates of the regression coefficient $b$ for all the pairs of dependent variable - independent variables, including the first pair as analysed above. Annex B lists the regression analysis results and the rates of the rest coefficients carried out under the same procedure as analysed indicatively for the $1^{\text {st }}$ regression test.

Table 9. Regression coefficient of independent - dependent variable(s)

Dependent Variable

Satisfaction from the Erasmus+ mobility overall experience

\begin{tabular}{lc} 
Independent Variables & Regression coefficient $b$ \\
\hline Help & 0.5405 \\
Facilities \& equipment & 0.6240 \\
Trainee's needs and organization & 0.6139 \\
Astuteness & 0.4512 \\
Contemporary skills & 0.4509 \\
Perception abilities & 0.4400 \\
Way of thinking & 0.5108 \\
Organization/Cooperation in the team & 0.4973 \\
Personal improvement & 0.5771 \\
Improvement through teamwork & 0.5648 \\
New challenges/situations & 0.5569 \\
Critical mind & 0.5493 \\
Interest in exogenous factors & 0.5276 \\
Job opportunities & 0.5172 \\
Perception on work issues & 0.5072 \\
Work abroad & 0.5324 \\
\hline
\end{tabular}


After the completion of all regressions, positive correlations were observed between the independent variables and the dependent variable 'Satisfaction from the Erasmus + mobility overall experience'. This shows that the more satisfaction the respondents get from each independent variable, the more satisfaction they get from their participation in Erasmus + mobility as a whole.

\section{Discussion on the Findings and Answers to Research Questions}

\subsection{Discussion on the Findings}

This section presents the findings' analysis of the survey regarding the degree of the respondents' satisfaction from the Erasmus+ mobility experience, as shown in the question section of the research tool.

In the "Quality of Studies/Training" section of the questionnaire, students stated they were satisfied both in the field of teaching and learning and in the support received from the sending and hosting organizations.

In the section "Foreign Language Skills and Linguistic Support", students believe that they have not improved (86\%), as they consider that they already had language competence. At this point we have to mention that one of the criteria for selecting students to participate in the programme is the knowledge of the English language, something that may explain the students' point of view without, however, diminishing the fact that the learning process in a foreign language may also improve the existing language skills.

The "Personal Development" section draws conclusions on knowledge, skills/competences and behaviors/attitudes acquired during the Erasmus + mobility. The participating students believe (Fully agree/Agree) that they have improved/developed skills in science, in technology, digital skills, sociopolitical skills, personal development skills (soft skills), etc.

In the section "Future Prospects of Education, Training and Work", the students agreed that after participating in the programme they acquired better opportunities for work in their country and abroad. Their contact with the real world of working abroad seems to have helped them.

\subsection{Answering the Research Questions}

As for the first research question concerning the effectiveness of the Erasmus + actions in relation to the acquisition of new skills and/ or their improvement, relating to vocational education, the results were positive. In particular, according to the students' views, as resulting from the processing of their responses to the programme's questionnaire, the actions carried out helped them. In other words, they were effective in developing or improving knowledge and skills related to the participants' vocational education and training.

As for the second research question exploring the effectiveness of the programme's actions in terms of the increase of the level of skills relating to foreign languages, the results showed, according to the students' views, that there wasn't any. Therefore, this category of actions seems to be proved ineffective. 


\section{Macrothink

In the third research question about the effectiveness of Erasmus+'s actions in relation to the personal improvement and the participants' development, a high degree of effectiveness was found since students agree that this category of actions contributed to their personal improvement and development significantly.

In the fourth research question, which examined the effectiveness of the programme's actions in improving the potential of the participants concerned with their employment and their future career prospects, all respondents agreed on their effectiveness and importance.

Finally, students' overall assessment on the degree of satisfaction with the Erasmus+ mobility experience was very positive, as $95.29 \%$ of the students stated that they were very satisfied. This is presented as a normal consequence of the respondents' views on all areas of the programme.

The statistical analysis of the data showed that the independent variables defining the mobility programme objectives, according to the views of the participating students, relate to their general satisfaction with the experience of mobility. Therefore, it appears that the effectiveness and the positive impact of the mobility program in this case study are substantiated, according to the objectives set.

\subsection{Instead of a Conclusion}

The Erasmus+ programme has been implemented in Greece since 2015. In 2015, there were 228 applications and 129 were approved and funded. In 2019, in the field of Learning Mobility of Individuals - Mobility Project for VET learners and staff, 378 applications were submitted after the National Call for Proposals to the Erasmus+ Programme and 183 were approved and funded. This means that the number of applications and the interest on this programme are constantly increasing.

Studying the specific case of schools in the prefecture of Preveza, through the participants' views, what is identified is the positive impact of the Erasmus + program. The programme enhances technical knowledge, competences and skills. It also contributes to the acquisition of personal and social skills and to the future prospect of their employment in their own country or abroad. Considering the programme objectives about the employability enhancement, it seems that they are achieved at least at the theoretical level and in accordance with the participants' views. The contribution of other socio-economical factors, however, is required so that this (possible) effect may give tangible results. A further comparative study, after the Erasmus + programme participants' school graduation, which would investigate their professional career path, in relation to those who did not participate in an Erasmus+ programme, could provide valid answers on the degree of impact of the programme on employability. However, this would require the establishment and operation of an organized structure aiming at the graduates interconnection and monitoring, i.e. a graduate observatory structure.

\section{Notes}

Note 1 . The term Social identity describes the total perceptions and attitudes that the person develops in society. This characteristic may either strengthen or debilitate a person's 
competitiveness in the labour market.

Note 2. Further analysis in the next section.

Note 3. Employability, labour market, economic activity.

Note 4. Further analysis in following sections of the article.

Note 5. Including the actions of the programme examined in this article, Erasmus + .

Note 6. «Participant Report»

Note 7. Please see: https://webgate.ec.europa.eu/eac/mobility

Note 8. State Scholarships Foundation (IKY) for Greece

Note 9. Information on the mobility programmes, the participants and the sending organizations in Annex A

Note 10. The same procedure is followed for all regression analyses presented in Annex B.

\section{References}

Aliber, Z. R., \& Click, W. R. (1993). Reading in International Business: A decision approach. Cambridge: The MIT Press.

Boutsiouki, S. (2017). European Policy on Education From the Lisbon Strategy to the "Europe 2020”. Athens: Stamouli.

Brennan, J., Mills, J., Shah, T., \& Woodley, A. (2000). Lifelong Learning for Employment and Equity: the Role of Part - Time Degrees. Higher Education Quarterly, 54, 411-418. https://doi.org/10.1111/1468-2273.00168.

Brown, P., Hesheth, A., \& Williams, S. (2003). Employability in a Knowledge - driven Economy. Journal of Education and Work, 16, 107-126. https://doi.org/10.1080/1363908032000070648.

Carnoy, M., \& Rhoten, D. (2002). What Does Globalization Mean for Educational Change? A Comparative Approach. Comparative Education Review, 46, 1-9. https://doi.org/10.1086/324053.

Dale, R. (2010). Specifying Globalization Effects On National Policy: A Focus On The Mechanisms. Journal of Education Policy, 14, 1-17. https://doi.org/10.1080/026809399286468.

European Commission. (2020a). What is Erasmus+? Retrieved from https://ec.europa.eu/programmes/erasmus-plus/about_en

European Commission. (2020b). Erasmus + Programme Guide 2020. Retrieved from https://ec.europa.eu/programmes/erasmusplus/sites/erasmusplus2/files/erasmus_programme_guide_2020_v2_en.pdf

Gonzalez, J., \& Wagenaar, R. (2003). Tuning Educational Structure in Europe. Bilbao: 
Universidad de Deusto.

Gouvias, S. D., \& Therianos, N. K. (2014). Educational Policy. Athens: Gutenberg.

Hillage, J., \& Pollard, E. (1998). Employability: Developing a framework for policy analysis. Retrieved from https://www.researchgate.net/publication/225083565_Employability_ Developing_a_framework_for_policy_analysis

Hirst, P., Thompson, G., \& Bromley, S. (2009). Globalization in question. Cambridge: Polity Press.

Jenkins, A. (2004). Women, lifelong learning and employment. London: Centre for the Economics of Education - London School of Economics and Political Science.

Jenkins, A., Vignoles, A., Wolf, A., \& Galindo-Rueda, F. (2003). The determinants and labour market effects of lifelong learning. Applied Economics, 35, 1711-1721. https://doi.org/10.1080/0003684032000155445.

Kavasakalis, A. (2018). Training and lifelong learning policies. In Th. Sakellaropoulos, Xr. Oikonomou, Xr. Skamnakis, \& M. Aggelaki (Eds.), Social Policy. Athens: Dionikos, ISBN: 9789606619830.

Kelpanidis, H. M., \& Vrynioti, P. K. (2004). Lifelong Learning. Athens: Ellinika Grammata.

McQuaid, R. W., \& Lindsay, C. (2005). The Concept of Employability. Urban Studies, 42, $197-$ 219. https://doi.org/10.1080/0042098042000316100.

Moreau, P. M., \& Leathwood, C. (2007). Graduates' employment and the discourse of employability: A critical analysis. Journal of Education and Work, 19, 305-324. https://doi.org/10.1080/13639080600867083.

OECD. (1997). Lifelong Learning to Maintain Employability. Retrieved from http://www.oecd.org/officialdocuments/publicdisplaydocumentpdf/?cote=OCDE/GD(97) $162 \&$ docLanguage $=$ En

Official Journal of the European Union. (2013). Regulation of the European Parliament and of the Council, of 11 December 2013, Establishing "Erasmus +": The Union Programme for Education, Training, Youth and Sport and Repealing Decisions No1719/2006/EC, No1720/2006/EC and No1298/2008/EC.L347/50, 20/12/2013.

Stamelos, G., \& Vasilopoulos, A. (2013). Lifelong learning policies in the context of European governance - The Greek case. Athens: Dionikos.

Stamelos, G., Vasilopoulos, A., \& Kavasakalis, A. (2015). Introduction to Educational Policies. [e-book.] Athens: Hellenic Academic Libraries Link. ISBN: 978-618-82124-9-7. Retrieved from http://hdl.handle.net/11419/226.

Stromquist, P. N., \& Monkman, K. (2014). Globalization and Education: Intergration and Contestation across Culture. U.S.A: Rowman \& Littlefield Education.

Tsaousis, D. G. (2007). The Educational Policy of International Organizations - Global and 


\section{Macrothink

European Dimensions. Athens: Gutenberg.

\section{Appendix}

Appendix 1. Data concerning programmes, population and mobility flows

In this study, we explored the participating students' views of the VET school units of Preveza prefecture on the Erasmus + individual mobility programmes. The following data are analysed on a per year basis.

Table 10. Data concerning mobility programmes

\begin{tabular}{|c|c|}
\hline \multicolumn{2}{|r|}{ Year 2015} \\
\hline Erasmus + project code & 2015-1-EL01-KA102-013513 \\
\hline School name & $1^{\text {st }}$ EPAL of Preveza \\
\hline Projects' flows & 3 \\
\hline Participants & 36 \\
\hline Host countries & Spain, Germany, Italy \\
\hline Erasmus + project code & 2015-1-EL01-KA102-013265 \\
\hline School name & $1^{\text {st }}$ EK of Preveza \\
\hline Projects' flows & 3 \\
\hline Participants & 45 \\
\hline Host countries & Germany, Estonia, Italy \\
\hline \multicolumn{2}{|r|}{ Year 2016} \\
\hline Erasmus + project code & 2016-1-EL01-KA116-023294 \\
\hline School name & $1^{\text {st }}$ EPAL of Preveza \\
\hline Projects' flows & 2 \\
\hline Participants & 30 \\
\hline Host countries & Spain, Italy \\
\hline Erasmus + project code & 2016-1-EL01-KA102-022935 \\
\hline School name & $1^{\text {st }}$ EK of Preveza \\
\hline Projects' flows & 3 \\
\hline Participants & 42 \\
\hline Host countries & Sweden, Germany, Italy \\
\hline \multicolumn{2}{|r|}{ Year 2017} \\
\hline Erasmus + project code & 2017-1-EL01-KA116-035866 \\
\hline School name & $1^{\text {st }}$ EPAL of Preveza \\
\hline Projects' flows & 3 \\
\hline Participants & 44 \\
\hline Host countries & Lithuania, Sweden, Germany \\
\hline Erasmus + project code & 2017-1-EL01-KA102-035365 \\
\hline School name & $1^{\text {st }}$ EPAL of Preveza \\
\hline Projects' flows & 3 \\
\hline Participants & 30 \\
\hline Host countries & Estonia, Spain, Italy \\
\hline \multicolumn{2}{|r|}{ Year 2018} \\
\hline
\end{tabular}




\section{Macrothink}

Erasmus + project code

School name

Projects' flows

Participants

Host countries

Appendix 2. Regression analyses between dependent - independent variables

The first regression analysis was carried out between the dependent variable "Satisfaction from the Erasmus+ overall experience" and the $1^{\text {st }}$ independent variable "Help". The results are presented in the following table.

Table 11. Regression analysis' results between Dependent Variable- $1^{\text {st }}$ Independent Variable "Help"

\begin{tabular}{ll}
\hline Multiple R & 0,8819 \\
$\mathrm{R}^{2}$ & 0,7778 \\
Adjusted R $^{2}$ & 0,7739 \\
Std. Error & 0,4722 \\
Statistical significance F & 83995 \\
$\mathrm{~B}_{0}$ & 0 \\
$\mathrm{~B}_{\text {help }}$ & 0,5405 \\
$\mathrm{P}_{\text {value (constant) }}$ & - \\
$\mathrm{P}_{\text {value (help) }}$ & 58281 \\
\hline
\end{tabular}

The regression coefficient $b=0,5405(>0)$ shows that there is a positive correlation, so $\mathrm{H}_{0}$ is rejected and we accept $\mathrm{H}_{1}$.

The second regression analysis was carried out between the dependent variable "Satisfaction from the Erasmus+ overall experience" and the $2^{\text {nd }}$ independent variable "Facilities \& equipment". The results are presented in the following table.

Table 12. Regression analysis' results between Dependent Variable- $2^{\text {nd }}$ Independent Variable "Facilities \& equipment"

\begin{tabular}{lc}
\hline Multiple R & 0,9148 \\
$\mathrm{R}^{2}$ & 0,8370 \\
Adjusted $\mathrm{R}^{2}$ & 0,8330 \\
Std. Error & 0,4045 \\
Statistical significance F & 7,8431 \\
$\mathrm{~B}_{0}$ & 0 \\
$\mathrm{~B}_{\text {Facilities \& equipment }}$ & 0,6240 \\
$\mathrm{P}_{\text {value (constant) }}$ & - \\
$\mathrm{P}_{\text {value (Facilities \& equipment) }}$ & 4,807 \\
\hline
\end{tabular}

The regression coefficient $b=0,6240(>0)$ shows that there is a positive correlation, so $\mathrm{H}_{0}$ is rejected and we accept $\mathrm{H}_{1}$.

The third regression analysis was carried out between the dependent variable "Satisfaction 


\section{1) Macrothink

from the Erasmus + overall experience" and the $3^{\text {rd }}$ independent variable "Trainee's needs and organization". The results are presented in the following table.

Table13. Regression analysis' results between Dependent Variable- $3^{\text {rd }}$ Independent Variable "Trainee's needs and organization"

\begin{tabular}{ll}
\hline Multiple R & 0,9218 \\
$\mathrm{R}^{2}$ & 0,8498 \\
Adjusted $\mathrm{R}^{2}$ & 0,8478 \\
Std. Error & 0,3878 \\
Statistical significance $\mathrm{F}$ & 1,7308 \\
$\mathrm{~B}_{0}$ & 0 \\
$\mathrm{~B}_{\text {Trainee's needs and organization }}$ & 0,6139 \\
$\mathrm{P}_{\text {value (constant) }}$ & - \\
$\mathrm{P}_{\text {value (Trainee's needs and organization) }}$ & 1,0245 \\
\hline
\end{tabular}

The regression coefficient $b=0,6139(>0)$ shows that there is a positive correlation, so $\mathrm{H}_{0}$ is rejected and we accept $\mathrm{H}_{1}$.

The fourth regression analysis was carried out between the dependent variable "Satisfaction from the Erasmus+ overall experience" and the $4^{\text {th }}$ independent variable "Astuteness". The results are presented in the following table.

Table 14. Regression analysis' results between Dependent Variable $-4^{\text {th }}$ Independent Variable "Astuteness"

\begin{tabular}{ll}
\hline Multiple R & 0,9105 \\
$\mathrm{R}^{2}$ & 0,8291 \\
Adjusted $\mathrm{R}^{2}$ & 0,8271 \\
Std. Error & 0,4137 \\
Statistical significance F & 1,268 \\
$\mathrm{~B}_{0}$ & 0 \\
$\mathrm{~B}_{\text {Astuteness }}$ & 0,4512 \\
$\mathrm{P}_{\text {value (constant) }}$ & - \\
$\mathrm{P}_{\text {value (Astuteness) }}$ & 7,9243 \\
\hline
\end{tabular}

The regression coefficient $b=0,4512(>0)$ shows that there is a positive correlation, so $\mathrm{H}_{0}$ is rejected and we accept $\mathrm{H}_{1}$.

The fifth regression analysis was carried out between the dependent variable "Satisfaction from the Erasmus+ overall experience" and the $5^{\text {th }}$ independent variable "Contemporary skills". The results are presented in the following table.

Table 15. Regression analysis' results between Dependent Variable- $5^{\text {th }}$ Independent Variable "Contemporary skills"

\begin{tabular}{ll}
\hline Multiple R & 0,9107 \\
$\mathrm{R}^{2}$ & 0,8294 \\
\hline
\end{tabular}




\section{Macrothink Institute"}

\begin{tabular}{ll}
\hline Adjusted $\mathrm{R}^{2}$ & 0,8274 \\
Std. Error & 0,4134 \\
Statistical significance F & 2,0981 \\
$\mathrm{~B}_{0}$ & 0 \\
$\mathrm{~B}_{\text {Contemporary skills }}$ & 0,4509 \\
$\mathrm{P}_{\text {value (constant) }}$ & - \\
$\mathrm{P}_{\text {value (Contemporary skills) }}$ & 1,3104 \\
\hline
\end{tabular}

The regression coefficient $b=0,4509(>0)$ shows that there is a positive correlation, so $\mathrm{H}_{0}$ is rejected and we accept $\mathrm{H}_{1}$.

The next regression analysis was carried out between the dependent variable "Satisfaction from the Erasmus+ overall experience" and the $6^{\text {th }}$ independent variable "Perception abilities". The results are presented in the following table.

Table 16. Regression analysis' results between Dependent Variable $-6^{\text {th }}$ Independent Variable "Contemporary skills"

\begin{tabular}{ll}
\hline Multiple R & 0,8860 \\
$\mathrm{R}^{2}$ & 0,7851 \\
Adjusted $\mathrm{R}^{2}$ & 0,7832 \\
Std. Error & 0,4639 \\
Statistical significance F & 6,0848 \\
$\mathrm{~B}_{0}$ & 0 \\
$\mathrm{~B}_{\text {Perception abilities }}$ & 0,44 \\
$\mathrm{P}_{\text {value (constant) }}$ & - \\
$\mathrm{P}_{\text {value (Perception abilities) }}$ & 4,1718 \\
\hline
\end{tabular}

The regression coefficient $b=0,44(>0)$ shows that there is a positive correlation, so $\mathrm{H}_{0}$ is rejected and we accept $\mathrm{H}_{1}$.

The next regression analysis was carried out between the dependent variable "Satisfaction from the Erasmus+ overall experience" and the $7^{\text {th }}$ independent variable "Way of thinking". The results are presented in the following table.

Table 17. Regression analysis' results between Dependent Variable $-7^{\text {th }}$ Independent Variable "Way of thinking"

\begin{tabular}{ll}
\hline Multiple R & 0,9117 \\
$\mathrm{R}^{2}$ & 0,8312 \\
Adjusted $\mathrm{R}^{2}$ & 0,8292 \\
Std. Error & 0,4112 \\
Statistical significance F & 1,9677 \\
$\mathrm{~B}_{0}$ & 0 \\
$\mathrm{~B}_{\text {Way of thinking }}$ & 0,5108 \\
$\mathrm{P}_{\text {value (constant) }}$ & - \\
$\mathrm{P}_{\text {value (Way of thinking) }}$ & 1,2234 \\
\hline
\end{tabular}




\section{MIMstitute"mk}

The regression coefficient $b=0,5108(>0)$ shows that there is a positive correlation, so $\mathrm{H}_{0}$ is rejected and we accept $\mathrm{H}_{1}$.

The next regression analysis was carried out between the dependent variable "Satisfaction from the Erasmus+ overall experience" and the $8^{\text {th }}$ independent variable "Organization/Cooperation in the team". The results are presented in the following table.

Table 18. Regression analysis' results between Dependent Variable- $8^{\text {th }}$ Independent Variable "Organization/Cooperation in the team"

\begin{tabular}{ll}
\hline Multiple R & 0,9142 \\
$\mathrm{R}^{2}$ & 0,8358 \\
Adjusted R & 0,8338 \\
Std. Error & 0,4056 \\
Statistical significance F & 12764 \\
$\mathrm{~B}_{0}$ & 0 \\
$\mathrm{~B}_{\text {Organization/Cooperation in the team }}$ & 0,4973 \\
$\mathrm{P}_{\text {value (constant) }}$ & - \\
$\mathrm{P}_{\text {value (Organization/Cooperation in the team) }}$ & 78462 \\
\hline
\end{tabular}

The regression coefficient $b=0,4973(>0)$ shows that there is a positive correlation, so $\mathrm{H}_{0}$ is rejected and we accept $\mathrm{H}_{1}$.

The $9^{\text {th }}$ regression analysis was carried out between the dependent variable "Satisfaction from the Erasmus+ overall experience" and the $9^{\text {th }}$ independent variable "Personal improvement". The results are presented in the following table.

Table 19. Regression analysis' results between Dependent Variable- $9^{\text {th }}$ Independent Variable "Personal improvement"

\begin{tabular}{ll}
\hline Multiple R & 0,9214 \\
$\mathrm{R}^{2}$ & 0,8491 \\
Adjusted $\mathrm{R}^{2}$ & 0,8478 \\
Std. Error & 0,3886 \\
Statistical significance F & 0 \\
$\mathrm{~B}_{0}$ & 0 \\
$\mathrm{~B}_{\text {Personal improvement }}$ & 0,5771 \\
$\mathrm{P}_{\text {value (constant) }}$ & - \\
$\mathrm{P}_{\text {value (Personal improvement) }}$ & 0 \\
\hline
\end{tabular}

The regression coefficient $b=0,5771(>0)$ shows that there is a positive correlation, so $\mathrm{H}_{0}$ is rejected and we accept $\mathrm{H}_{1}$.

The $10^{\text {th }}$ regression analysis was carried out between the dependent variable "Satisfaction from the Erasmus+ overall experience" and the $10^{\text {th }}$ independent variable "Improvement through teamwork". The results are presented in the following table

Table 20. Regression analysis' results between Dependent Variable- $10^{\text {th }}$ Independent Variable "Improvement through teamwork" 


\section{MIMacrothink}

Multiple $\mathrm{R}$ 2020, Vol.7, No.2

$\mathrm{R}^{2}$

0,9202

Adjusted $\mathrm{R}^{2}$

0,8467

Std. Error

0,8448

Statistical significance F

0,3918

$\mathrm{B}_{0}$

1,1334

0

B Improvement through teamwork

0,5648

$\mathrm{P}_{\text {value (constant) }}$

6,7668

$\mathrm{P}_{\text {value (Improvement through teamwork) }}$

The regression coefficient $b=0,5648(>0)$ shows that there is a positive correlation, so $\mathrm{H}_{0}$ is rejected and we accept $\mathrm{H}_{1}$.

The $11^{\text {th }}$ regression analysis was carried out between the dependent variable "Satisfaction from the Erasmus ${ }^{+}$overall experience" and the $11^{\text {th }}$ independent variable "New challenges/situations". The results are presented in the following table.

Table 21. Regression analysis' results between Dependent Variable- $11^{\text {th }}$ Independent Variable "New challenges/situations"

\begin{tabular}{lc}
\hline Multiple R & 0,9211 \\
$\mathrm{R}^{2}$ & 0,8485 \\
Adjusted $\mathrm{R}^{2}$ & 0,8466 \\
Std. Error & 0,3894 \\
Statistical significance F & 1,4446 \\
$\mathrm{~B}_{0}$ & 0 \\
$\mathrm{~B}_{\text {New challenges/situations }}$ & 0,5569 \\
$\mathrm{P}_{\text {value (constant) }}$ & - \\
$\mathrm{P}_{\text {value (New challenges/situations) }}$ & 8,5816 \\
\hline
\end{tabular}

The regression coefficient $b=0,5569(>0)$ shows that there is a positive correlation, so $\mathrm{H}_{0}$ is rejected and we accept $\mathrm{H}_{1}$.

The next regression analysis was carried out between the dependent variable "Satisfaction from the Erasmus + overall experience" and the $12^{\text {th }}$ independent variable "Critical mind". The results are presented in the following table.

Table 22. Regression analysis' results between Dependent Variable- $12^{\text {th }}$ Independent Variable "Critical mind"

\begin{tabular}{lc}
\hline Multiple R & 0,9204 \\
$\mathrm{R}^{2}$ & 0,8472 \\
Adjusted $^{2}$ & 0,8452 \\
Std. Error & 0,3912 \\
Statistical significance F & 3,7303 \\
$\mathrm{~B}_{0}$ & 0 \\
$\mathrm{~B}_{\text {Critical mind }}$ & 0,5493 \\
$\mathrm{P}_{\text {value (constant) }}$ & - \\
$\mathrm{P}_{\text {value (Critical mind) }}$ & 2,224 \\
\hline
\end{tabular}




\section{1) Macrothink

The regression coefficient $b=0,5493(>0)$ shows that there is a positive correlation, so $\mathrm{H}_{0}$ is rejected and we accept $\mathrm{H}_{1}$.

The next regression analysis was carried out between the dependent variable "Satisfaction from the Erasmus+ overall experience" and the $13^{\text {th }}$ independent variable "Interest in exogenous factors". The results are presented in the following table.

Table 23. Regression analysis' results between Dependent Variable- $13^{\text {th }}$ Independent Variable "Interest in exogenous factors"

\begin{tabular}{lc}
\hline Multiple R & 0,9201 \\
$\mathrm{R}^{2}$ & 0,8466 \\
Adjusted $\mathrm{R}^{2}$ & 0,8453 \\
Std. Error & 0,3918 \\
Statistical significance $\mathrm{F}$ & 0 \\
$\mathrm{~B}_{0}$ & 0 \\
$\mathrm{~B}_{\text {Interest in exogenous factors }}$ & 0,5276 \\
$\mathrm{P}_{\text {value (constant) }}$ & - \\
$\mathrm{P}_{\text {value (Interest in exogenous factors) }}$ & 0 \\
\hline
\end{tabular}

The regression coefficient $b=0,5276(>0)$ shows that there is a positive correlation, so $\mathrm{H}_{0}$ is rejected and we accept $\mathrm{H}_{1}$.

The next regression analysis was carried out between the dependent variable "Satisfaction from the Erasmus+ overall experience" and the $14^{\text {th }}$ independent variable "Job opportunities". The results are presented in the following table.

Table 24. Regression analysis' results between Dependent Variable- $14^{\text {th }}$ Independent Variable "Job opportunities"

\begin{tabular}{ll}
\hline Multiple R & 0,9147 \\
\hline $\mathrm{R}^{2}$ & 0,8367 \\
Adjusted R $^{2}$ & 0,8347 \\
Std. Error & 0,4044 \\
Statistical significance F & 31244 \\
$\mathrm{~B}_{0}$ & 0 \\
$\mathrm{~B}_{\text {Job opportunities }}$ & 0,5172 \\
$\mathrm{P}_{\text {value (constant) }}$ & - \\
$\mathrm{P}_{\text {value (Job opportunities) }}$ & 19161 \\
\hline
\end{tabular}

The regression coefficient $b=0,5172(>0)$ shows that there is a positive correlation, so $\mathrm{H}_{0}$ is rejected and we accept $\mathrm{H}_{1}$.

The next regression analysis was carried out between the dependent variable "Satisfaction from the Erasmus+ overall experience" and the $15^{\text {th }}$ independent variable "Perception on work issues". The results are presented in the following table. 


\section{Macrothink

Table 25. Regression analysis' results between Dependent Variable- $15^{\text {th }}$ Independent Variable "Perception on work issues"

\begin{tabular}{ll}
\hline Multiple R & 0,9131 \\
$\mathrm{R}^{2}$ & 0,8338 \\
Adjusted R $^{2}$ & 0,8318 \\
Std. Error & 0,4080 \\
Statistical significance F & 10903 \\
$\mathrm{~B}_{0}$ & 0 \\
$\mathrm{~B}_{\text {Perception on work issues }}$ & 0,5072 \\
$\mathrm{P}_{\text {value (constant) }}$ & - \\
$\mathrm{P}_{\text {value (Perception on work issues) }}$ & 67356 \\
\hline
\end{tabular}

The regression coefficient $b=0,5072(>0)$ shows that there is a positive correlation, so $\mathrm{H}_{0}$ is rejected and we accept $\mathrm{H}_{1}$.

The next regression analysis was carried out between the dependent variable "Satisfaction from the Erasmus+ overall experience" and the $16^{\text {th }}$ independent variable "Work abroad". The results are presented in the following table.

Table 26. Regression analysis' results between Dependent Variable- $16^{\text {th }}$ Independent Variable "Work abroad"

\begin{tabular}{ll}
\hline Multiple R & 0,91 \\
$\mathrm{R}^{2}$ & 0,8284 \\
Adjusted $\mathrm{R}^{2}$ & 0,8264 \\
Std. Error & 0,4146 \\
Statistical significance F & 37788 \\
$\mathrm{~B}_{0}$ & 0 \\
$\mathrm{~B}_{\text {Work abroad }}$ & 0,5324 \\
$\mathrm{P}_{\text {value (constant) }}$ & - \\
$\mathrm{P}_{\text {value (Work abroad) }}$ & 23658 \\
\hline
\end{tabular}

The regression coefficient $b=0,5324(>0)$ shows that there is a positive correlation, so $\mathrm{H}_{0}$ is rejected and we accept $\mathrm{H}_{1}$.

Finally, the $17^{\text {th }}$ regression analysis was carried out between the dependent variable "Satisfaction from the Erasmus + overall experience" and the $17^{\text {th }}$ independent variable "Working in an international context". The results are presented in the following table.

Table 27. Regression analysis' results between Dependent Variable- $17^{\text {th }}$ Independent Variable "Working in an international context"

\begin{tabular}{lc}
\hline Multiple R & 0,9213 \\
$\mathrm{R}^{2}$ & 0,8489 \\
Adjusted $\mathrm{R}^{2}$ & 0,8449 \\
Std. Error & 0,3894 \\
Statistical significance F & 52021 \\
\hline
\end{tabular}




\section{Macrothink

$\mathrm{B}_{0}$

0

B Working in an international context

0,4842

$\mathrm{P}$ value (constant)

$\mathrm{P}$ value (Working in an international context)

30837

The regression coefficient $b=0,4842(>0)$ shows that there is a positive correlation, so $\mathrm{H}_{0}$ is rejected and we accept $\mathrm{H}_{1}$.

\section{Copyright Disclaimer}

Copyright reserved by the author(s).

This article is an open-access article distributed under the terms and conditions of the Creative Commons Attribution license (http://creativecommons.org/licenses/by/3.0/). 